\title{
THE EFFECTIVENESS OF STEM BASED LEARNING IN IMPROVING SCIENTIFIC THINKING ABOUT GRADE V OF ELEMENTARY SCHOOL
}

\author{
Badarudin \\ Universitas Muhammadiyah Purwokerto, INDONESIA
}

Received 28 December 2020 • Revised 25 January 2020 • Accepted 24 March 2021

\begin{abstract}
This study is backgrounded by student's scientific attitude which is still low in process of Natural Sciences in grade V SD/MI. The present study aimed to determine the improvement of scientific attitudes by using learning based on Science, Technology, Engineering, and Mathematics (STEM). This study is a class action research. Subjects of this study are students of class $V$ in MI Muhammadiyah Kramat with a total of 20 students, consisting of 15 men and 5 women. The instrument used is a questionnaire and a scientific attitude observation sheet as well as a science learning achievement test. The results of this study there is an increase in scientific attitudes and learning achievement using the STEM model in grade V. Based on the questionnaire scientific attitude in the first cycle to get an average score of 3.7 or $74 \%$ which includes good criteria and then increased in the second cycle to get an average score of 4.2 or $84 \%$ which includes good criteria. Improvement of science learning achievement in the first cycle got an average value of 55.1 with $40.3 \%$ mastery learning and cycle II got an average value of 71.65 with $82 \%$ mastery learning. Each stage in STEM can facilitate the improvement of scientific attitudes in learning science in grade $\mathrm{V}$ $\mathrm{SD} / \mathrm{Ml}$.
\end{abstract}

Keywords: Scientific Attitudes, Science Learning, STEM

\section{INTRODUCTION}

The challenge of an educator is to provide an education system that creates opportunities for students to connect knowledge and skills so that they become familiar with each student. Elementary School (SD) is one of formal education. As formal education, elementary school is the initial foundation for the inculcation of concepts and strategic places in shaping the character of students in the formation of attitudes and skills for students so that they are able to compete, be ethical, moral, polite, have attitudes and skills as a provision to enter the next level of education. Children in primary school age generally enjoy learning and feeling or doing it directly. This means that elementary school children have the potential to have a scientific attitude.

Natural Sciences (IPA) as one of the subjects taught in elementary school provides an opportunity for children to develop their thinking skills in explaining a problem and practicing skills[1]. One effort to improve the quality of science education is through the learning process. Science learning can require students to be involved in scientific activities, so they can develop scientific attitudes. Students will be more likely to solve problems using reason rather than their feelings. The scientific attitude possessed by students needs to be further developed and improved. [2], [3] explains that to develop students' scientific attitudes there are three main types of teacher roles namely: showing examples, providing reinforcement with praise and approval, and providing opportunities to develop attitudes.

Scientific attitudes are behaviors obtained through providing positive examples and must continue to be developed so that students can have them. Scientific attitude is an attitude that emphasizes students to learn according to facts. [4], [5] argues that, scientific attitudes are behaviors or actions such as rational learning scientists. George [6] also suggested that scientific attitude in learning science is very important to be developed because scientific attitude is closely related to the achievement of science. The need for modeling in science learning that 
leads to student activities in actively seeking, processing, constructing, and using knowledge, needs to be a consideration for teachers in formulating science learning.

Based on the results of observations and information obtained from the grade V teacher MI Muhammadiyah Kramat data obtained that the scientific attitude of students is still low. The low scientific attitude of students is evidenced by students who tend to be passive and not motivated to want to know when there is a new subject matter. Inaccuracy and lack of caution or haste in drawing conclusions without data and facts. Especially when required to come to the front of the class to explain something or argue about something based on facts students tend to be afraid to move forward, they do not dare to go forward to explain and their ability to explain based on facts or data is still weak. Another problem found was the low learning achievement of Natural Sciences. Based on the information from the grade V teachers, it was obtained that the results of the odd semester assessment (PTS) of 27 students had 12 students or $44 \%$ got grades below the minimum completeness criteria (KKM) so that to improve student learning achievement, the teacher conducted remedial activities.

Based on these conditions, students are deemed necessary to make improvements in learning aimed at improving scientific attitudes and student achievement. This requires teachers to be more creative and innovative in carrying out teaching and learning activities. Quality improvement during the learning process for elementary students needs to be done through improving the learning process, this is so that students can learn well, the teaching methods used by teachers must be as precise, efficient and effective as possible [7]. The use of concrete teaching aids by the teacher is expected to help the scientific attitude. High scientific attitude is a necessary condition in learning science. The formation of scientific attitudes of students, it will have an impact on learning achievement is increasing. Based on the considerations and results of discussions conducted with grade $\mathrm{V}$ teachers, the researchers applied Science, Technology, Engineering and Mathematics (STEM) based learning.

STEM learning directly provides training to students to be able to integrate each aspect at once. STEM learning is defined as the skill of using knowledge and scientific processes in understanding natural phenomena and manipulating these phenomena so that they can be implemented [8]. The learning process that involves all four aspects will shape the knowledge about the subject being studied more understood. These four aspects are a matching pair between problems that occur in the real world and also problem-based learning [9]. STEM can create a cohesive learning system and active learning because all four aspects are needed simultaneously to solve problems. The solutions provided show that students can unify abstract concepts from every aspect. STEM learning combines the skills and knowledge that are used simultaneously by students [10]. Several studies on STEM learning such as the integration of project-based learning into STEM in improving the scientific literacy of elementary school students [11] and the effect of STEM learning implementation on students' perceptions, attitudes, and creativity [12]. STEM learning has been effectively applied in developed countries, but it is still relatively new in Indonesia as

a developing country. It is hoped that STEM learning can be applied more broadly and deeply in Indonesia [12]. STEM has the meaning of teaching and learning related to the fields of Science, Technology, Engineering, and Mathematics. STEM learning can not only be done at the level of primary and secondary education but can also be carried out up to the level of lectures and even up to postdoctoral levels. The benefits of continuous STEM learning should be demonstrated by early education and at the stage, students can combine cognitive and psychomotor knowledge [13]. STEM learning will provide an introduction to students after passing through school [14].

Based on the problems and phenomena that have been described previously, the authors are interested in researching the effectiveness of the STEM-based learning model in improving scientific attitudes in the fifth grade of elementary schools. Innovations in the research carried out are the habit of reading before learning in the initial learning activities in the hope that students have preliminary knowledge of the material to be learned as well as forming the habit of fond of reading in children

\section{MATERIAL AND METHODS}

\section{Methods}

This study uses classroom action research conducted collaboratively between researchers and classroom teachers. The research design used is the spiral reflection design [15]. In this spiral reflection design, research is focused on scientific attitudes and student achievement after participating in learning with the STEM model. The main objective of the study is to determine the improvement of scientific attitude by using learning based on the STEM model in class V MI Muhammadiyah Kramat. Besides, this study will also describe the implementation of STEM learning in facilitating the improvement of scientific attitudes of elementary school students. The subjects of this study were 20th grade $\mathrm{V}$ students, consisting of 15 men and 5 women.

\section{Instrument}

The instruments in this study used tests and a non-tests. The test consists of: a set of test questions to measure 
learning achievement. While the instrument in the form of a non-test is a Linkert scale questionnaire to measure students' scientific attitudes and observation sheets of STEM learning implementation and learning tools that follow the learning steps in using the STEM model. Indicators of scientific attitudes that are used adopt from [2], [16] namely nine aspects of scientific attitudes that can be developed in elementary school-age children, such as curiosity, wanting to get something new, cooperation, not hopeless, not prejudiced, introspective Responsible, freethinking and self-discipline. Indicators of success in this Classroom Action Research are: (1) an increase in scientific attitudes of students of at least $80 \%$ of the total number of students with good grades; and (2) an increase in student learning achievement in science subjects by using STEM learning at least $80 \%$ of the number of students who have met the KKM is 70 with good criteria.

\section{Procedures}

This study uses classroom action research procedures. The research focused on problems in the classroom, then researchers seek solutions to problems that occurred in the class. Classroom action research is characterized by cycles. The cycle conducted in this classroom action research consisted of 2 cycles. Every one cycle there are two meetings. At the end of each cycle an evaluation will be held to determine the development of scientific attitudes and student achievement. The class action research model used is the Kemmis and Mc. Taggart [15]. The Kemmis and Mc. Taggart consists of four stages of activity, namely the planning (plan), action (action), observation (observation), and reflection (reflection) stages. Classroom action research will be carried out using STEM learning.

\section{Data Analysis}

Data analysis conducted by compilation researchers has obtained the data obtained, both obtaining research data through a test or non-test technique. Data analysis conducted by researchers included analysis of student learning achievement assessment data, analysis of teacher activity observation sheets, analysis of student activity observation sheets, student observation scientific observation sheets and student leadership assessment scale questionnaire analysis. The data analysis is intended to make it easier for researchers to analyze all the data and findings that researchers find.

\section{RESULTS AND DISCUSSION}

This study uses classroom action research procedures. Research focused on problems that exist in the classroom, then researchers find solutions to problems that occur in the class. Classroom action research is characterized by cycles. The cycle carried out in this class action research consisted of two cycles. Every one cycle there are two meetings. At the end of each cycle an evaluation will be held to determine the development of scientific attitudes and student achievement. This researcher uses four stages of activities, namely planning, action, observation, and reflection.

In the planning stage researchers and teachers discuss together related research that includes the introduction and helping teachers understand STEM learning. The next step is the researcher making lesson plans and research instruments, as well as the division of tasks in conducting learning and observation activities. Learning is focused on theme 8 in class $\mathrm{V}$ according to the lesson schedule at the time the research took place.

At the action or implementation stage the teacher applies the STEM model with the steps from [17], [18] as follows: (1) Reflection stage: provide problem orientation to students, to bring students into the learning context. Explain the learning objectives and activities to be carried out; (2) Research Phase: organizing students to research, the teacher submits material and lures students to be actively involved when learning to either ask questions, answer teacher questions, or express opinions; (3) Discovery stage: involves collecting data or material making hypotheses, explanations, and giving examples of real conditions or events that exist in life. The teacher helps students collect information from various sources, the teacher helps link the material with real events that occur around students; (4) Application Stage: The teacher helps form groups, conduct experiments, create works, develop, discuss solutions to solving real events that have been conveyed. Students can discuss, exchange opinions, clarify, explain, conduct experiments or make work. There are written results in the form of solutions to problems that will be presented in front of the class or there are products of work from students; and (5) Communication Phase: analyzing and evaluating the problem-solving process, the teacher helps students to analyze the

results of discussions or the work of students. The teacher helps students provide grades and suggestions for presentations that have been made so that in the next learning the students can be even better.

At the observation stage or observations made during the learning process takes place using the STEM model. 
During the observation process the researchers used teacher activity observation sheets and student scientific attitude activity sheets. At the reflection stage, the researcher and the teacher evaluate the results of the learning implementation. The purpose of this activity is to obtain input and improvement for further learning activities based on data obtained from the results of observations and evaluations that have been analyzed. The results of reflection from learning for each cycle and learning can be explained as follows:

\section{Reflection Results of Cycle I Meeting 1}

Reflecting on the cycle 1 meeting, the researcher conducted a discussion with observer 2, observer 3 , and the teacher regarding teacher performance, the difficulties faced by the teacher when practicing the steps of learning in accordance with the lesson plan, and the responses of the fifth grade students towards learning Theme 8 Subtheme 1 Meeting 1 that uses the STEM learning model. The results of the discussion during reflection, summarize the obstacles found in the first cycle of meeting 1, namely: (1) Still found students who did not pay attention and play alone. Students are not actively involved, this is seen when the teacher gives some questions that most students choose to be quiet and not answer. (3) There is no respect from students towards other students. This can be seen from students who are still noisy and play alone when there are representatives of groups who appear to present the results of the discussion or practicum. (4) Students do not care about the answers they give when working in groups. This can be seen when working in groups or discussions that are limited by students without thinking about whether the answer is correct or not. Also, the results of the discussion are written briefly and less regularly. (5) The results obtained during the evaluation of meeting 1 in the first cycle were less than half the number of grade $\mathrm{V}$ students who passed the KKM reaching 70, then mastery learning was less than $50 \%$.

Countermeasures that can be done to fix these obstacles are researchers planning better learning activities so that the next meeting does not encounter obstacles like the previous meeting. Solutions to these obstacles include: (1) The teacher provides motivation and tells students that it is necessary to respect others so that we are also valued by others. Before the group work presentation process, the teacher needs to warn students to be calm and pay attention to students who present the results of group work. The goal is that group discussion activities can run effectively. (2) The teacher motivates and accustoms students to maximize answers for each task or question. The teacher accustoms students to writing and stringing words to develop answers. It needs help from the teacher. The goal is that students can express their thoughts in written form. (3) The teacher more often provides attribution of material to real-life students. Occasionally the teacher gives questions. The goal is that students more easily understand the material presented by the teacher, and lure students to be actively involved in learning.

\section{Reflection Results of Cycle I Meeting 2}

The results of the discussion during reflection, summarizing the obstacles found in the first cycle of meeting 2 include the following: (1) When dividing groups and explanations related to student worksheet not all of them pay attention. This can be seen when the group process there are still students who are confused and ask the teacher. (2) When presenting the results of group work there are still some students who have not focused on learning. The teacher occasionally reminds students to stay focused on students who are presenting the results of group work, but not long after some students begin to make noise again. This shows the lack of awareness and concern for students. (3) The results of the evaluation of students in cycle I meeting 2 have not reached the expected percentage of mastery learning. This is proven because of the total number of grade V students, only half completed.

Countermeasures solutions that can be done to improve these obstacles are researchers planning better learning activities and so that the next meeting does not encounter obstacles like the previous meeting. Handling for these constraints includes: (1) When submitting the worksheet the teacher makes sure students pay attention. The goal is that the teacher does not convey the same thing repeatedly. (2) Occasionally giving strict action to students who do not want to pay attention to their friends. The goal is that students realize that their noisy behavior and disrespect for friends who are presenting are not good. (3) When delivering the material, the teacher is better to give an example in real life as a stimulus for understanding the material. The goal is that students can better understand when delivering the material.

\section{Reflection Results of Cycle II Meeting 1}

The results of reflection in the second cycle of meeting 1 are as follows: (1) Still found students who have not been able to condition during the learning such as talking to his friend, so that disturbing his friend who was watching the teacher when learning took place. (2) The results of the evaluation cycle II meeting 1 that there are still some students who have not yet finished working on the evaluation sheet.

Countermeasures that can be done to improve these obstacles are researchers planning better learning activities 
so that the next meeting does not encounter obstacles like the previous meeting. Solutions to these obstacles include: (1) The need for awareness of each student to participate in learning calmly and in an orderly manner. So that the learning process runs effectively and optimally. (2) Students pay more attention and focus when delivering the material by the teacher, so they can work on evaluations. When students do not understand the material, you should ask the teacher or the teacher who offers students who want to ask.

\section{Reflection Results of Cycle II Meeting 2}

The obstacles encountered in the second cycle of meeting 2 are: (1) Students who have special needs still cannot finish working on the evaluation questions. (2) There are still students who talk to their friends when the teacher delivers material in front of the class. The solutions that can be done to overcome these obstacles are: (2) Teachers more often provide understanding, understanding, and attention to students with special needs. (2) The teacher emphasizes and is not bored to warn students who play or talk with their friends.

\section{DISCUSSION}

\section{Improving Student Scientific Attitudes}

Every meeting during using the learning model of Science, Technology, Engineering, and Mathematics (STEM) the scientific attitude of students has increased. This effects on the evaluation conducted at the end of the meeting, by following the opinion [19], [20] that learning in elementary schools emphasizes the provision of learning directly through the use and development of scientific process skills and attitudes. This Classroom Action Research during the student learning process does not only study theory, the teacher invites students to develop problem-solving solutions, develop thoughts, and practicum.

The increased scientific attitude for each meeting has increased. The scientific attitude of students in the first cycle looks very low because the number of students who are active and pay attention to the teacher's explanation is only 8 out of 20 students. The results of scientific attitudes in Cycle I Meeting 1 had an average of 3.40 or $68 \%$ including the criteria of lack, at meeting 2 had an average of 4.10 or $82 \%$ including criteria either, between meetings 1 and 2 in the first cycle there was an increase of $14 \%$. The average scientific attitude questionnaire in Cycle I gained 3.70 or $74 \%$, including good criteria. Whereas in the second cycle meeting 1 had an average of 4.14 or $83 \%$ including good criteria, at meeting 2 had an average of 4.27 or $85 \%$ including a good criterion, between meetings 1 and 2 in cycle II an increase of $2 \%$. So the average scientific attitude questionnaire for the second cycle students get 4.20 or $84 \%$ including good criteria. The criteria obtained have reached research achievements.

Improved scientific attitudes occur not apart from teachers who are actively involved in learning. Researchers found findings during the second cycle of learning the teacher linked the material with real-life examples that were around students, the teacher linked groundwater material to the process of absorbing water on bricks. Students are very enthusiastic because the examples given by the teacher are around the lives of students, so it is easier to understand the material. When a group activity makes a simple water filter, students discuss it so that the group activity runs effectively.

Improved scientific attitudes occur periodically and gradually. Each meeting the teacher tries to ask questions that arouse students' curiosity so students want to find out more and ask questions. Seen when the teacher asks questions related to the environment, students respond enthusiastically. Researchers found findings when students advanced to convey the results of discussions about groundwater and surface water that other students were able to calm down and appreciate who presented the results of the discussion. Besides, when practicum making simple water filtration, students can already discuss and work together effectively. In Indonesia the scientific attitude that must be trained first is the ability to respect others and the courage of students to answer questions, ask questions, and discuss, to develop these behaviors requires rules and motivation from the teacher in class ${ }^{16}$. The teacher also provides motivation for students to be actively involved in learning. Seen when the teacher gives an example of the surrounding rice field environment in the village of Kramat, students immediately respond to the stimulus from the teacher. Besides, during groundwater group work, students discuss and exchange ideas about why bricks can absorb water and stones cannot, which makes students who don't know. The improvement in scientific attitudes is seen when working in a simple water filter making group, the teacher presents problems related to the availability of clean water which is getting thinner, then students discuss with each other to find and develop solutions to solving the problem of the availability of clean water that is running low. The STEM characteristics emphasize more 


\section{Improved Learning Achievement}

Improved learning achievement is seen when teachers teach using the STEM learning model that combines Indonesian, IPA, and SBdP subjects, the findings are consistent with the opinion [21], [22] that Science, Technology, Engineering, and Mathematics (STEM) is learning that combines two or more fields of science. The teacher associates one material with other subject matter in one learning, in this way makes students more able to think freely. The combination of Indonesian and Science subjects makes students get a real picture of a material.

Researchers found the increase occurred because students responded more to the teacher when the teacher gave the linkage of the material benefits of water with the student's real life. Besides, when the teacher gives an assignment to find out the difference between groundwater and surface water, students do the practicum first with bricks and stones to observe the difference, after practicum students discuss to find out the difference. When the discussion process students get new information and make students increase knowledge. Increased mastery of learning science in each meeting and cycle. The findings that researchers found were that the more scientific attitudes of students increased student achievement, it was in line with the theory revealed [2], [16] there were nine aspects of scientific attitudes that could be developed in elementary school-age children, increasing scientific attitudes were in line with increasing development of student thinking that can improve student understanding of a material, so that it can improve student learning outcomes.

The increase in learning achievement of Natural Sciences in cycle I meeting 1 was 48.5, cycle I meeting 2 was 61.7, cycle II meeting 1 was 67.37 , and cycle II meeting 2 was 76 . The average value of natural science subjects had increased periodically and continuously. The learning process is carried out by following the learning implementation plan. The researcher observed that when the research took place it appeared that students were following the learning well, the evaluations of the students working had increased in each cycle and meeting. Learning is a process by which a person undertakes to obtain a new change in behavior as a whole, as a result of his own experience in interactions with the environment 7 . The improvement of students' learning completeness in science subjects during the research cycle I meeting 1 was $25 \%$, cycle I meeting 2 was $55.6 \%$, cycle II meeting 1 was $79 \%$, and cycle II meeting 2 was $85 \%$. Mastery learning in natural science subjects has increased periodically and continuously.

The teacher has an important role in the learning process, in the first cycle of meeting 1 the teacher did not understand deeply what the STEM learning model was. After reflection, the teacher has better understood the steps and what is the STEM learning model. So that at the next meeting the teacher presents questions and examples in real life. The purpose of this activity is to provide stimulus to students to develop scientific attitudes.

When group activities students are given space to discuss each other, for example developing solutions to a problem. Students can express their opinions and think freely without any limitation, to make students' creative thinking develop optimally.

\section{CONCLUSION}

Based on the results and discussion of classroom action research conducted at MI Muhammadiyah Kramat, it can be concluded that the use of the STEM model can improve scientific attitudes and science learning achievements in class V. Increased scientific attitudes in the first cycle get an average score of 3.7 or $74 \%$ those that included good criteria then increased in cycle II to get an average score of 4.2 or $84 \%$ which included good criteria. Improvement of science learning achievement in the first cycle got an average value of 55.1 with $40.3 \%$ mastery learning and cycle II got an average value of 71.65 with $82 \%$ mastery learning. Learning is said to be successful because it has achieved an indicator of success in learning completeness of at least $80 \%$.

Some suggestions in this research that can be considered are as follows: (1) In practicum activities with the model of Science, Technology, Engineering, and Mathematics (STEM) need to pay attention to time so that learning runs effectively. The goal is that students can experiment and think more freely without constraints of limited practicum time; (2) To further improve student learning and scientific attitudes, teachers should provide guided practice exercises to students by providing practice questions that lead to problem-solving and scientific steps; and (3) Good for teachers, schools, and researchers who will implement STEM learning so make learning activities more interesting by providing expected innovations so as to bring up new findings that can improve the quality of learning better. 


\section{REFERENCES}

[1] Samatowa, U. (2010). Pembelajaran IPA di Sekolah Dasar. Jakarta: PT. Indeks.

[2] Harlen, W. (1993). Teaching and Learning Primary Science. London. Paul Chapman Publishing Ltd.

[3] Rapi N.K (2008). Implementasi Siklus Belajar Hipotesis-Deduktif untuk Meningkatkan Sikap Ilmiah dan Keterampilan Proses IPA di SMAN 4 Singaraja. Jurnal Pendidikan dan Pengajaran. no. 3. 701-720.

[4] Chandra, D.T. (2007) Memilih Buku Pelajaran IPA. http:// pelangi.ditplp.go.id.

[5] Hayat, M.S., Anggraeni, S. \& Redjeki, S. (2011). Pembelajaran Berbasis Praktikum pada Konsep Invertebrata untuk Pengembangan Sikap Ilmiah Siswa. Jurnal Bioma. 1(2). 141-152.

[6] Singh, K.V. (2016). A Study of the Relationship between Scientific Attitude and Academic Achievement of Rural Area's Intermediate College Girl (science stream only). International Journal of applied research. 2(4). 46-49

[7] Slameto. (2010). Belajar dan Faktor-Faktor yang Mempengaruhinya. Jakarta: Rienaka Cipta.

[8] Hannover Research. (2011). Successful K-12 STEM Education: Identifying Effective Approaches in Science, Technology, Engineering, and Mathematics. Washington, DC: National Academies Press.

[9] Torlakson. T. (2014). Innovate A Blueprint for Science, Technology, Engineering, and Mathematics in California Public Education. California: State Superintendent of Public Instruction.

[10] Pfeiffer, H.D, Ignatov, D.I., \& Poelmans, J. (2013). Conceptual Structures for STEM Research and Education. 20th International Conference on Conceptual Structures, Proceedings ICCS 2013 January 10-12. Mumbai: Springer.

[11] [11] Afriana, J., Permanasari, A. \& Fitriani, A. (2016). Project-Based Learning Integrated To Stem To Enhance Elementary School's Students Scientific Literacy. Jurnal Pendidikan IPA Indonesia. JPII, 5 (2). 261-267

[12] Sari, R.H. (2017). Pengaruh Implementasi Pembelajaran STEM terhadap Persepsi, Sikap, dan Kreativitas Siswa. Prosiding Seminar Nasional MIPA III. Langsa-Aceh, October 30, available in: http://www.conference.unsyiah.ac.id/SN-MIPA

[13] [Gonzalez, H.B. \& Kuenzi, J. J. (2012). Science, Technology, Engineering, and Mathematics (STEM) Education: A Primer. Congressional Research Service.

[14] [14] White, D.W. (2010). What Is STEM Education and Why Is It Important?. Florida Association of Teacher Educators Journal. 1(14). 1-9.

[15] Kemmis, S \& Robin Mc.Taggart. (1982). The Action Research Planner. Victoria: Deakin University Press.

[16] [Alawiyah, I \& Sopandi, W. (2016). Pembelajaran Berbasis Proyek untuk Meningkatkan Sikap Ilmiah Siswa Sekolah Dasar pada Materi Peristiwa Alam. Jurnal Penelitian Pendidikan UPI. ISSN: 1412-565X. 167 - 176

[17] Laboy-Rush, D. (2019). Integrated STEM Education through Project-based Learning. 2010. (Online) (www.learning.com/stem/whitepaper/integrated-STEM-throughProject-basedLearning), accessed on October 10.

[18] Jauhariyyah, F.R., Suwono, H., \& Ibrohim. (2017). Science, Technology, Engineering, and Mathematics Project Based Learning (STEM-PjBL) pada Pembelajaran Sains. Prosseding Seminar Pendidikan IPA Pascasarjana UM. Vol.2. 432436

[19] Mulyasa, E. (2015). Menjadi Guru Profesional (Menciptakan Pembelajaran Kreatif dan Menyenangkan). Bandung: PT Remaja Rosda Karya.

[20] [20] Karli, H. (2011). Pendekatan Ketrampilan Proses untuk Meningkatkan Sikap Ilmiah pada Mata Pelajaran IPA Siswa Kelas III SD “X” Serpong. Jurnal Pendidikan Dasar UPI. 3(1), 1-15

[21] Ismayani, A. (2016). Pengaruh Penerapan STEM Project- based Learning terhadap Kreativitas Matematis siswa SMK. Indonesian Digital Journal of Mathematics and Education. 3(4), 264-272.

[22] [Utami, T.N., Jatmiko, A., \& Suherman. (2018). Pengembangan Modul Matematika dengan Pendekatan Science, Technology, Engineering, and Mathematics (STEM) pada Materi Segiempat. Desimal: Jurnal Matematika. 1

\section{http://jurnalnasional.ump/index.php/dinamika}

